\title{
From Tumor Immunology to Immunotherapy in Gastric and Esophageal Cancer
}

\author{
David Vrána ${ }^{1}$ @ , Marcel Matzenauer ${ }^{1}$, Čestmír Neoral ${ }^{2}$, René Aujeský ${ }^{2}$, Radek Vrba ${ }^{2, *}$, \\ Bohuslav Melichar ${ }^{1}$, Nikol Rušarová ${ }^{1}$, Marie Bartoušková ${ }^{1}$ and Janusz Jankowski ${ }^{3}$ \\ 1 Department of Oncology, Faculty of Medicine and Dentistry, Palacky University, Hnevotinska 976/3, \\ 77515 Olomouc, Czech Republic; davvrana@gmail.com (D.V.); mmatzenauer@me.com (M.M.); \\ Bohuslav.Melichar@fnol.cz (B.M.); ni.ru@seznam.cz (N.R.); bartouskova.m@seznam.cz (M.B.) \\ 2 Department of Surgery, Faculty of Medicine and Dentistry, Palacky University, Hnevotinska 976/3, \\ 77515 Olomouc, Czech Republic; Cestmir.Neoral@fnol.cz (Č.N.); rene.aujesky@gmail.com (R.A.) \\ 3 National Institute for Health and Care Excellence, London SW1A 2BU, UK; prof.jankowski@outlook.com \\ * Correspondence: Radek.Vrba@fnol.cz; Tel.: +420-588-442-415
}

Received: 24 November 2018; Accepted: 17 December 2018; Published: 20 December 2018

check for updates

\begin{abstract}
Esophageal and gastric cancers represent tumors with poor prognosis. Unfortunately, radiotherapy, chemotherapy, and targeted therapy have made only limited progress in recent years in improving the generally disappointing outcome. Immunotherapy with checkpoint inhibitors is a novel treatment approach that quickly entered clinical practice in malignant melanoma and renal cell cancer, but the role in esophageal and gastric cancer is still poorly defined. The principal prognostic/predictive biomarkers for immunotherapy efficacy currently considered are PD-L1 expression along with defects in mismatch repair genes resulting in microsatellite instability (MSI-H) phenotype. The new molecular classification of gastric cancer also takes these factors into consideration. Available reports regarding PD-1, PD-L1, PD-L2 expression and MSI status in gastric and esophageal cancer are reviewed to summarize the clinical prognostic and predictive role together with potential clinical implications. The most important recently published clinical trials evaluating checkpoint inhibitor efficacy in these tumors are also summarized.
\end{abstract}

Keywords: esophageal cancer; gastric cancer; immunotherapy; checkpoint inhibitors; microsatellite instability

\section{Introduction}

Esophageal and gastric cancers are among the top ten most frequent and deadly tumors worldwide [1]. The etiology of both tumors is poorly understood, but bacterial, viral, and environmental factors are thought to play a substantial role. Since the percentage of adenocarcinoma of the esophagus is increasing rapidly over time (especially in Western countries where adenocarcinoma already is more common than squamous cell carcinoma) esophageal cancer will be discussed together with gastric cancer in which adenocarcinoma is the most prevalent histology. The treatment strategy, however, differs significantly. Primary surgical resection with adjuvant chemotherapy or chemoradiotherapy or perioperative chemotherapy are the principal treatment strategies for gastric cancer, while for esophageal cancer, neoadjuvant chemoradiotherapy followed by surgical resection is the current gold standard. Unfortunately, the prognosis of both disorders remains disappointing despite significant effort in the both clinical and preclinical research [2-4].

One of the fundamental evasion mechanisms of cancer cells, defined by Hanahan and Weinberg as "hallmarks of cancer", is the alteration of the host immune system which allows tumor growth in a relatively hostile environment. The physiological role of the immune checkpoints is to 
prevent excessive immune response by termination of immune system activation at appropriate time. Tumor cells can use this mechanism to catalyze the auto-destruction of the immune response. These mechanisms are at the center of interest of the research aiming to sustain the activity of the immune system to allow the tumor cells to be destroyed, and acting on the immune checkpoints seems to be a promising option. Immunotherapy has established a firm position in the treatment of malignant melanoma, lung cancer, and clear-cell renal cancer, but its role in the treatment of esophageal and gastric cancer is much less defined [5-7].

The aim of the present review is to summarize the recent developments of immunotherapy in gastric and esophageal cancers with reference to key developments in other epithelial cancers.

\section{Molecular Subtypes of Esophageal and Gastric Cancer}

Esophageal squamous cancer is stratified into three distinct molecular subgroups based on the gene analysis. The Cancer Genome Atlas Research Network research group has evaluated 90 esophageal squamous cell carcinomas (ESCC). The first subgroup ESCC1 includes tumors, which respond poorly to chemoradiotherapy and are, generally, associated with poor prognosis. The principal genomic alteration identified is NRF2 pathway disruption. The second subgroup is ESCC2, characterized by the mutation of NOTCH1, ZNF750, KDM6A, KDM2D, PTEN, PIK3R1, and CDK6 amplification. This subgroup is also associated with white blood cell infiltration. The last molecular subgroup ESCC3 is characterized by Phosphoinositide 3-kinase (PI3K) pathway disruption. Unfortunately, at present this stratification of squamous cell esophageal carcinoma lacks any specific clinical impact. At the same time, the proportion of MSI-H SCC is very low compared with gastric cancer [8].

Similarly, esophageal and gastroesophageal junction adenocarcinomas (EGADCs) have also been molecularly characterized. Secrier et al. [9] have reported the results of the whole-genome sequencing of 129 esophageal adenocarcinomas also distinguishing three major molecular subtypes. The first subgroup are the tumors with dominant $\mathrm{C}>\mathrm{A} / \mathrm{T}$ mutations, the second subgroup is mainly defective in homologous recombination/chromosome segregation, and the last subgroup has commonly $T>G$ mutation with high mutation burden. Compared with the previous sub-classification of ESCCs, where clinical impact is minimal, the possible clinical importance in EGADC is obvious. The last subgroup of tumors with both high mutation loads and high number of neoantigens could be appropriate for the immunotherapy with checkpoint inhibitors. The second subgroup, similar to breast cancer patients with the BRCA mutation, could contain candidates for Poly (ADP-ribose) polymerase (PARP) inhibitors due to the disrupted homologous recombination. However, in the first subgroup of EGADC patients, chemotherapy remains the treatment of choice until further targeted therapy is available [9].

Last but not least, there is a gastric cancer sub-classification that was published in 2014 by the Cancer Genome Atlas Research Network. Gastric cancer was sub-classified into four major subtypes based on the molecular pattern. The most frequent subgroup of tumors is characterized by chromosomal instability (CIN) representing about $50 \%$ of all patients. This group of patients is characterized by TP53 mutation and RAS pathway disruption. Histologically this subgroup is characterized mostly by intestinal histology. Typically, there are several potential targets for the targeted therapy present (human epidermal growth factor receptor 2 (HER2), epidermal growth factor receptor (EGFR), tyrosine-protein kinase Met (MET)), but so far, except for trastuzumab, with limited clinical impact. The second most common subgroup are the tumors with microsatellite instability (MSI-H) representing about $22 \%$ of the patients. The evidence regarding the clinical impact of the MSI has been rapidly growing during the last few years and will be discussed in more detail below. The third subgroup of the tumors representing about $20 \%$ of the cases is called genomically stable (GC) tumors. Histologically, these tumors are characterized by diffuse histology and genetically by the CDH1/RHOA or CLDN18-ARHGAP mutations. The last subgroup of the tumors consists of tumors 
with Epstein-Barr virus (EBV) infection characterized by mutation of PIK3CA, CDKN2A silencing and $P D-L 1 / 2$ over-expression which is also discussed in more detail below [10].

\section{Immune Checkpoints PD-1/PD-L1/PD-L2 and Clinical Significance in Gastric and Esophageal Cancer}

Immune checkpoint receptor PD-1 is a co-inhibitory molecule that is physiologically expressed on immune cells such as $\mathrm{T}$ and $\mathrm{B}$ lymphocytes or myeloid cells providing the signal for the termination of immune system activity. PD-1 receptor has two natural ligands, PD-L1 (B7-H1) and PD-L2 (B7-DC), which can be expressed, in addition to immune cells, also in tumor cells, and represent a potential mechanism of immune surveillance escape [11].

Generally, PD-L1 expression was considered to be a poor prognostic factor for patient outcome across different tumor types. However, it has been recently demonstrated that the situation is more complex, and PD-L1 may indicate protective as well as poor prognostic risks depending on the tumor subtype, disease stage, or prior treatment. Unfortunately, the predictive role of PD-L1 expression for the efficacy of immunotherapy did not meet clinicians' expectations and is, in many settings, poorly defined.

The reports on the prognostic role of the PD-L1 expression in esophageal or gastric cancer are summarized in Table 1 . The published data are highly heterogeneous in terms of disease stage (stage ranging from I to IV), treatment (surgery alone, neoadjuvant treatment, adjuvant treatment, or advanced line treatment), different methods of PD-L1 status evaluation (immunohistochemistry vs. RT-PCR), different antibodies which may recognize different parts of the PD-L1 and heterogeneity of the cells on which the expression was assessed (tumor cells, stromal cells, or lymphocytes), different cutoffs for positivity that ranges widely $(1-50 \%)$ One of the potential pitfalls may also be associated with the fact that most of the trials were performed in Asian populations alone. The findings also reflect the heterogeneity of the patients enrolled in the trials ranging from better prognosis for patients expressing PD-L1 to worse prognosis. From the research papers reported there are, however, several issues that deserve special attention and have potentially clinical implications.

\subsection{PD-L1 Expression and Radiotherapy}

Interesting findings were reported regarding radiotherapy and PD-L1 expression. Radiotherapy of localized esophageal cancer in neoadjuvant setting represents the gold standard of treatment. At the same time, adjuvant radiochemotherapy is the standard treatment for locally advanced gastric cancer after surgical resection. Zhang et al. have irradiated the esophageal squamous cell lines by using $6 \mathrm{MV}$ linear accelerator with several $2 \mathrm{~Gy}$ fractions evaluating the PD-L1 expressing during the treatment. The data demonstrated an increasing expression of the PD-L1 during the treatment [19]. One of potential explanations of this observation is the induction of the immune response by the tumor destruction by the radiotherapy-induced immune response, and selection of PD-L1 expressing tumor cells. These findings are crucial in clinical practice since $2 \mathrm{~Gy}$ fractionation is, as mentioned above, the standard neoadjuvant/radical treatment approach. Considering these findings, immunotherapy could potentially improve outcome, specifically in the adjuvant setting. Several trials are currently investigating the role of immunotherapy in adjuvant setting after neoadjuvant chemoradiotherapy of esophageal/gastroesophageal junction cancer (CheckMate 577) [38] with no results reported so far, but in other tumor types, e.g., lung cancer, the administration of adjuvant immunotherapy (durvalumab) has resulted in significant improvement in patient outcome [39]. Additionally, PD-L1 expression seems to correlate with the response to neoadjuvant chemoradiotherapy and may be used to select patients who could potentially be spared from surgery after neoadjuvant chemoradiotherapy [40]. Finally, it has been demonstrated that the PD-L1 expression increases with increase in the total radiation dose. Years before programmed death receptor/ligands discovery, it was observed in the Intergroup 123 trial that an increased radiation dose (from 50 to 66 Gy) did not improve patient outcome in esophageal cancer [41], which was surprising considering the fact that 
radical doses for squamous cell cancer of other locations is usually close to $70 \mathrm{~Gy}$. These findings were explained by the increased toxicity of the radiotherapy, but, considering the above-mentioned findings, one potential explanation could be an increasing resistance of the tumor cells associated with increased PD-L1 expression. Chen et al. have also reported significantly increased level of PD-L1 expression in patients not responding to neoadjuvant chemoradiotherapy compared with responders ( $72 \%$ versus $35 \%$ ). This finding correlated with pathologic complete response achieved (16\% versus $31 \%$ ) [23]. The exact mechanism of increased PD-L1 expression is unknown, but there are several hypotheses. One of the viable explanations may be the increased secretion of interferon-gamma by the CD8+ T cell lymphocytes which stimulates PD-L1 expression as demonstrated by Dovedi et al. [42] (Figure 1). Interferon-gamma increases the PD-L1 expression through the Janus kinases-Signal Transducer and Activator of Transcription proteins (JAK-STAT) pathway. At the same time, increased PD-L1 expression is associated with epithelial-mesenchymal transition phenotype [43] which can further increase the tumor malignant (metastatic) potential.

These observations again highlight the fact that PD-L1 expression level is highly dependent on the previous treatment and makes its evaluation even more complicated.

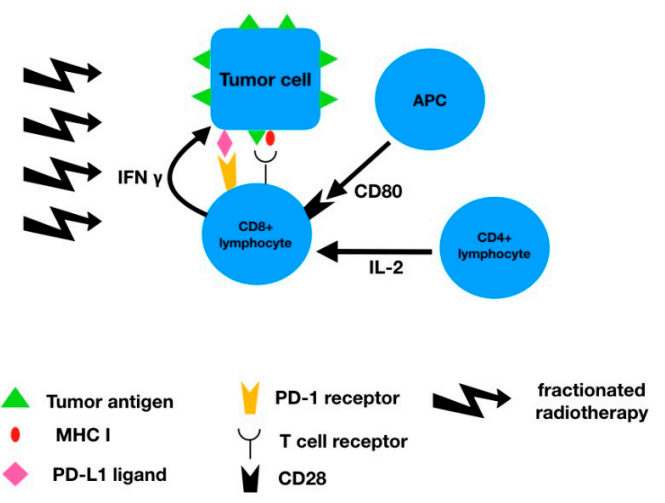

Figure 1. Connection of radiotherapy and PD-L1 expression.

\subsection{PD-L1 Expression and Systemic Treatment}

Another interesting point mentioned in these reports is the association of PD-L1 expression with the systemic treatment. The most frequently used chemotherapy regimens for both esophageal and gastric cancer include cisplatin, oxaliplatin, doxorubicin, 5-fluorouracil, paclitaxel, and docetaxel.

In contrast to radiotherapy in which PD-L1 expressions is increasing during the treatment and correlates with the total dose delivered, cisplatin-based chemotherapy in gastric cancer seems to decrease the expression of the PD-L1, specifically in responding tumors [26]. The simplest explanation for this could be the decreased total tumor mass, which corresponds with decreased PD-L1 positive tumor cells. However, the situation may be more complicated. Ghebeh et al. have shown that doxorubicin may translocate PD-L1 on breast cancer cells from the cell surface to the nucleus in association with the activity of the PI3K/AKT pathway [44]. Doxorubicin has been known to have immune-modulatory potential for decades and this can be potential explanation for this effect. Similarly, another anthracyclin epirubicin that is also used in gastric and esophageal cancer decreases PD-L1 level in breast cancer cell lines. On the other hand, some reports are suggesting that other cytotoxic agents such as paclitaxel can increase the expression of PD-L1 [45]. At the same time, 5-FU, probably the most widely used chemotherapeutic agent in gastric and esophageal cancer, was demonstrated to increase the PD-L1 expression as well [46]. Considering these observations, using immunotherapy may be more appropriate with or after taxane/5-FU-based chemotherapy. Again, chemotherapy regiments that have been used for a long time such as cisplatin/5-FU, carboplatin/paclitaxel, epirubicin/cisplatin/5-FU (ECF), or docetaxel/cisplatin/5-FU (DCF) could be also effective because of compensating effect on PD-L1 expression. 
Table 1. Prognostic significance of PD-L1 expression in gastric and esophageal cancer.

\begin{tabular}{|c|c|c|c|c|c|c|c|c|}
\hline Author & $\begin{array}{c}\text { Number of } \\
\text { Patients }\end{array}$ & Type of Cancer & Histology & Disease Stage & Percentage of PD-L1+ & $\begin{array}{l}\text { Prognosis } \\
(\text { (PD-L1+) }\end{array}$ & Prognostic Value & Reference \\
\hline Böger $C$ et al. & 465 & gastric cancer & adenocarcinoma & all stages & $\begin{array}{l}\text { tumor cells: } 30.1 \% \text { (primary cancer), } 60 \% \\
\text { (liver metastases) immune cells: } 88.4 \% \\
\text { (primary cancer), } 73.3 \% \text { (liver metastases) }\end{array}$ & better & $\begin{array}{l}\text { improved OS and tumor specific } \\
\text { survival }\end{array}$ & [12] \\
\hline Pereira MA et al. & 287 & gastric cancer & adenocarcinoma & all stages & $8.8 \%$ & no impact & no impact & [13] \\
\hline Tamura $\mathrm{T}$ et al. & 431 & gastric cancer & adenocarcinoma & all stages & $29.6 \%$ & worse & worse OS for stage II/III & [14] \\
\hline Zhang L et al. & 132 & gastric cancer & adenocarcinoma & II/III & $50.8 \%$ & worse & worse OS & [15] \\
\hline Eto $S$ et al. & 105 & gastric cancer & adenocarcinoma & II/III & $24.7 \%$ & worse & $\begin{array}{c}\text { worse OS (statistically } \\
\text { non-significant) }\end{array}$ & [16] \\
\hline Tsutsumi et al. & 90 & esophageal cancer & SCC & localized & $36.6 \%$ & worse & worse OS and relapse free survival & [17] \\
\hline Kim R et al. & 200 & esophageal cancer & SCC & localized & $33.5 \%$ & worse & $\begin{array}{l}\text { worse locoregional relapse rate } \\
\text { and distant metastasis rate, no } \\
\text { change in OS }\end{array}$ & [18] \\
\hline Zhang $\mathrm{W}$ et al. & 344 & esophageal cancer & SCC & II/III & tumor cells $14.5 \%$, immune cells $24.7 \%$ & better & $\begin{array}{l}\text { better OS and DFS only in immune } \\
\text { cells PD-L1+ }\end{array}$ & [19] \\
\hline Zhu Y et al. & 133 & esophageal cancer & SCC & pT3pN0M0 & $42.1 \%$ & worse & worse DFS and OS & [20] \\
\hline Jiang Y et al. & 428 & esophageal cancer & SCC & $\begin{array}{l}\text { localized and } \\
\text { metastatic }\end{array}$ & $79.7 \%$ & worse & $\begin{array}{l}\text { worse DFS and OS in radically } \\
\text { treated patients }\end{array}$ & [21] \\
\hline Jesinghaus M et al. & 125 & esophageal cancer & SCC & all stages & $71 \%$ tumor cells, immune cells $87 \%$ & better & $\begin{array}{l}\text { better OS, DSS and DFS (PD-L1+ } \\
\text { tumor cells) }\end{array}$ & [22] \\
\hline Chen MF et al. & 162 & esophageal cancer & SCC & not specified & $45.7 \%$ & worse & worse treatment response and OS & [23] \\
\hline Kawazoe A et al. & 487 & gastric cancer & adenocarcinoma & localized & tumor cells $22.8 \%$, immune cells 61.4 & no impact & no impact & [24] \\
\hline Thompson ED et al. & 34 & gastric cancer & adenocarcinoma & localized & tumor cells $12 \%$, immune cells $44 \%$ & worse & worse PFS and OS & [25] \\
\hline Yang JH et al. & 72 & gastric cancer & adenocarcinoma & IV & $58.3 \%$ & better & better PFS & [26] \\
\hline Seo AN et al. & 116 & gastric cancer & adenocarcinoma & localized & tumor cells $49.1 \%$, stromal cells $56.9 \%$ & worse & worse DFS, not OS & [27] \\
\hline Ito $S$ et al. & 90 & esophageal cancer & SCC & localized & $19 \%$ & worse & worse OS & [28] \\
\hline Hsieh CC et al. & 150 & esophageal cancer & SCC & localized & $64 \%$ & worse & worse DFS & [29] \\
\hline Kollmann D et al. & 168 & esophageal cancer & adenocarcinoma & localized & tumor cells $43.5 \%$, immune cells $69 \%$ & better & tumor cells expression - better DFS & [30] \\
\hline Tanaka K et al. & 180 & esophageal cancer & SCC & localized & $29.4 \%$ & worse & $\begin{array}{l}\text { worse OS for patients after } \\
\text { neoadjuvant chemotherapy }\end{array}$ & [31] \\
\hline Li Z et al. & 137 & gastric cancer & adenocarcinoma & all stages & $40.9 \%$ & worse & worse OS & [32] \\
\hline Wang L et al. & 550 & gastric cancer & adenocarcinoma & all stages & $37.3 \%$ & no impact & not associated & [33] \\
\hline Saito $R$ et al. & 96 & gastric cancer & adenocarcinoma & not specified & tumor cells $34 \%$, stromal cells $45 \%$ & worse & worse OS and DSS & [34] \\
\hline Cho J et al. & 78 & gastric cancer & adenocarcinoma & all stages & $9 \%$ tumor cells, $60.3 \%$ immune cells & better & better OS (immune cells PD-L1+) & [35] \\
\hline Ma C et al. & 44 & gastric cancer & adenocarcinoma & all stages & $72 \%$ & no impact & not associated & [36] \\
\hline Koh J et al. & 392 & gastric cancer & adenocarcinoma & II/III & $25 \%$ & no impact & not associated & [37] \\
\hline
\end{tabular}

SCC: squamous cell cancer, OS: overall survival, DFS: disease free survival, PFS: progression free survival, DSS: disease-specific survival. 


\subsection{PD-L1 Expression and EBV Infection}

Another frequently reported observation is the correlation of PD-L1 expression with EBV. EBV is human double stranded DNA virus (herpesviridae) which is a well-known cause of nasopharyngeal carcinoma or Burkitt lymphoma, but the relation with gastric cancer is less documented. Gastric cancer associated with EBV infections seems to more frequently express the PD-L1 and represent a disease with better prognosis. The mechanism for PD-L1 expression is probable related to latent membrane protein 1 (LMP1) and interferon-gamma stimulated by EBV which up-regulate the expression of PD-L1 [47]. EBV infection could potentially serve as another predictive marker for anti-PD-L1 directed immunotherapy not only in gastric cancer.

\subsection{PD-L1 Expression and MSI Status}

Importantly, MSI-H as a result of DNA mismatch repair gene deficiency is related to increased PD-L1 expression and better prognosis. The mechanism of PD-L1 over-expression in MSI-H situation can be explained by the fact that an increased number of neoantigens resulting from MSI-H phenotype attract a high number of $\mathrm{T}$ lymphocytes which stimulate PD-L1 expression through secretion of interferon-gamma [48].

\subsection{PD-L1 Expression and Epithelial-Mesenchymal Transition Phenotype}

Epithelial-mesenchymal transition (EMT) phenotype is an important step in the metastatic cascade of malignant tumors. EMT corresponds to the loss of epithelial cell phenotype (cell adhesion and polarity) and gaining of mesenchymal phenotype with aggressive potential. Gaining this potential seems to correlate with PD-L1 expression due to the presence in the promotor region of the PD-L1 of a binding site for Zinc finger E-box-binding homeobox 1 (ZEB1) transcription factor which is at the same time related to EMT. As a result of this dual action of ZEB1 protein, the tumors with PD-L1 expression and EMT phenotype have worse prognosis [49].

\subsection{PD-L1 Expression and EGFR}

The relationship between EGFR and PD-L1 expression is more complicated. EGFR expression seems to be immunosuppressive and correlates with low PD-L1 expression (again potentially explained by low interferon-gamma level due to lack of tumor infiltrating lymphocytes). The data showed that radiotherapy could induce PD-L1 expression and the administration of EGFR and EGFR inhibitors could counteract this aberrant PD-L1 expression [50]. Predictive role of PD-L1 is further discussed below.

PD-L2 has the same receptor as PD-L1, but its prognostic or predictive role is much less defined. The same applies for prognostic/predictive role of PD-1 receptor. From the published reports (summarized in Table 2) no prognostic value is apparent regarding the patient outcome as well as immunotherapy efficacy. 
Table 2. Prognostic significance of PD-1/PD-L2 expression in gastric and esophageal cancer.

\begin{tabular}{|c|c|c|c|c|c|c|c|c|c|}
\hline & Author & $\begin{array}{l}\text { Number of } \\
\text { Patients }\end{array}$ & Type of Cancer & Histology & Disease Stage & $\begin{array}{c}\text { Percentage of } \\
\text { Positivity }\end{array}$ & Prognosis & Prognostic Value & Reference \\
\hline \multirow{5}{*}{ PD-1 } & Chen $\mathrm{K}$ et al. & 349 & esophageal cancer & SCC & localized & $33.5 \%$ & no impact & no impact & [51] \\
\hline & $\mathrm{Wu} \mathrm{Y}$ et al. & 340 & gastric cancer & adenocarcinoma & all stages & $22.6 \%$ & better & improved OS & [52] \\
\hline & Böger $C$ et al. & 465 & gastric cancer & adenocarcinoma & all stages & $\begin{array}{l}\text { primary cancer } 53.8 \% \text {, } \\
\text { liver metastases } 73.3 \%\end{array}$ & better & $\begin{array}{l}\text { improved tumor } \\
\text { specific survival }\end{array}$ & [12] \\
\hline & Eto $S$ et al. & 105 & gastric cancer & adenocarcinoma & $\mathrm{II} / \mathrm{III}$ & $26.7 \%$ & worse & worse DFS & [16] \\
\hline & Kollmann D et al. & 168 & esophageal cancer & adenocarcinoma & localized & $\begin{array}{l}\text { tumor cells } 77.4 \% \text {, } \\
\text { immune cells } 81 \%\end{array}$ & worse & worse OS and DFS & [30] \\
\hline \multirow{3}{*}{ PD-L2 } & Seo AN et al. & 116 & gastric cancer & adenocarcinoma & localized & $\begin{array}{l}\text { tumor cells } 21.6 \% \text {, } \\
\text { stromal cells } 38.8 \%\end{array}$ & no impact & $\begin{array}{c}\text { not statistically } \\
\text { significant trend } \\
\text { towards-improved DFS }\end{array}$ & [27] \\
\hline & Hsieh CC et al. & 150 & esophageal cancer & SCC & localized & $42 \%$ & no impact & no impact & [29] \\
\hline & Tanaka K et al. & 180 & esophageal cancer & SCC & localized & $48.3 \%$ & worse & $\begin{array}{l}\text { worse OS for patients } \\
\text { after neoadjuvant } \\
\text { chemotherapy }\end{array}$ & [31] \\
\hline
\end{tabular}

SCC: squamous cell cancer, OS: overall survival, DFS: disease free survival. 


\section{Significance of Microsatellite Instability}

Mismatch repair genes are the genes which replace nucleotides incorrectly incorporated during DNA replication. Damage of these repair genes was investigated in several tumor types and is also responsible for the most frequent hereditary form of colorectal cancer, i.e., Lynch syndrome. As a result of the defects in these genes (mismatch repair deficient phenotype; dMMR) there is a higher level of short repeated sequences of the DNA called microsatellites. High levels of microsatellite instability (MSI-H) are associated with several unique characteristics in relation to immunotherapy. Defects in DNA replication causes expression of defective proteins, which the immune system recognizes as neoantigens, and represents a potential target for immune cells. In the case of gastric cancer, the MSI-H phenotype correlates with high mutation burden (HMB) [53]. At the same time, attraction of the immune cells into the tumor environment is causing a high level of stimulatory cytokines (e.g., interferon-gamma). Taken all together, this constellation is pushing the immune balance towards immune stimulation and favorable clinical course. The principal immune cell populations responsible for tumor destruction are the CD3+ tumor infiltrating lymphocytes (TIL) including helper CD4+ and cytotoxic CD8+ lymphocytes while the principal suppressor cell subset is the FOXP3+ T cells [54]. It has been demonstrated in patients with colorectal cancer that the number of CD3+ and CD8+ immune cells is significantly increased in the MSI-H tumors, in contrast to FOX3+ T lymphocytes (T regs), whose level remains the same regardless of microsatellite instability [55].

In Table 3, a summary of reports evaluating the prognostic role of MSI-H in gastric cancer patients in presented. The percentage of MSI-H tumors in gastric cancer patients ranges from $8-25 \%$, but in the case of squamous cell esophageal cancer the MSI-H phenotype is quite rare [56-58]. Generally, in patients with gastric adenocarcinoma MSI-H phenotype represents a positive prognostic factor regardless the disease stage. Some interesting results have been reported regarding adjuvant/perioperative chemotherapy and microsatellite instability. A retrospective analysis of the MAGIC trial evaluating perioperative ECF chemotherapy in gastric cancer reported no clinical benefit of perioperative chemotherapy in patients with MSI-H tumors [59]. It may be hypothesized that immunostimulatory environment of the MSI-H tumors itself can represent positive prognostic factor for patient outcome after surgery that cannot be further improved by the administration of systemic chemotherapy. Moving step further, it may be reasonable to further boost the already activated immune system by the administration of immune checkpoint inhibitors which could potentially neutralize the increase of PD-L1 expression by the tumor cells in response to immune stimulation. This theoretical assumption was confirmed clinical trials (Keynote-016, -164, -012, -028, and -158) that included patients with MSI-H tumors (mainly colorectal cancer, but also including gastric cancer patients). The objective response rate was 39.6\%, which brought the US Food and Drug Administration (FDA) approval for pembrolizumab in several solid tumors including gastric cancer [60]. However, so far, there are no other trials confirming these results, and it should be also taken into consideration that the approval is based on just a few gastric cancer patients. 
Table 3. Prognostic and predictive role of MSI-H phenotype in gastric cancer.

\begin{tabular}{|c|c|c|c|c|c|c|c|}
\hline Author & Histology & Stage & $\begin{array}{c}\text { Number of } \\
\text { MSI-H Patients }\end{array}$ & MSI-H Frequency & $\begin{array}{l}\text { Prognostic Role of } \\
\text { MSI-H Phenotype }\end{array}$ & Prognostic/Predictive Value & Reference \\
\hline Kim $\mathrm{H}$ et al. & adenocarcinoma & all stages & 161 & $9 \%$ & better & improved prognosis & [61] \\
\hline An JY et al. & adenocarcinoma & all stages & 170 & $8.5 \%$ & no impact & $\begin{array}{c}\text { no benefit from adjuvant } \\
\text { chemotherapy in MSI-H patients }\end{array}$ & [62] \\
\hline Fang WL et al. & adenocarcinoma & I-III & 25 & $11.7 \%$ & better & $\begin{array}{c}\text { improved } 5 \text {-year OS (68\% vs. } \\
47.6 \%, p=0.030) \text {, trend towards } \\
\text { better DFS at } 3 \text { years }\end{array}$ & [63] \\
\hline Beghelli S et al. & adenocarcinoma & all stages & 83 & $16 \%$ & better & $\begin{array}{l}\text { improved survival in stage II } \\
\text { patients }\end{array}$ & [64] \\
\hline Kim SY et al. & adenocarcinoma & II-III & 105 & $8.2 \%$ & better & $\begin{array}{l}\text { improved prognosis without } \\
\text { chemotherapy }\end{array}$ & [65] \\
\hline Smyth EC et al. & adenocarcinoma & localized & 20 & $8.5 \%$ & better & $\begin{array}{l}\text { worse prognosis when treated } \\
\text { with chemotherapy }\end{array}$ & [59] \\
\hline Polom K et al. & adenocarcinoma & metastatic & 14 & $8.0 \%$ & better & $\begin{array}{l}\text { improved OS (15.9 vs. } 8 \text { months, } \\
\qquad p=0.023)\end{array}$ & [56] \\
\hline Giampieri R et al. & adenocarcinoma & metastatic & 15 & $14 \%$ & better & improved overall survival & [66] \\
\hline Corso G et al. & adenocarcinoma & all stages & 63 & $25.2 \%$ & better & improved long term survival & [57] \\
\hline Oki E et al. & adenocarcinoma & all stages & 22 & $9.4 \%$ & No prognostic role & No prognostic role & [67] \\
\hline Falchetti $\mathrm{M}$ et al. & adenocarcinoma & localized & 27 & $17 \%$ & better & improved survival $(p=0.1)$ & [68] \\
\hline Marrelli D et al. & adenocarcinoma & all stages & 111 & $23.5 \%$ & better & $\begin{array}{l}\text { improved } 5 \text {-year survival }(67.6 \% \\
\text { vs. } 35 \%, p<0.001)\end{array}$ & [69] \\
\hline
\end{tabular}




\section{Immunotherapy}

There are several current clinical trials, mostly with checkpoint inhibitors, investigating the role of immunotherapy in gastric and esophageal cancer. As mentioned above, there are subtypes of gastric cancer that could potentially be candidates for immunotherapy, including MSI-H tumors harboring multiple neoantigens resulting from mismatch repair gene deficiency as well as EBV-positive tumors expressing PD-L1/L2. These potentially immunogenic tumors represent about one-third of all tumors. The role of MSI phenotype was investigated in a phase I clinical trial where 15 tumor types were treated by pembrolizumab with promising results. The FDA has approved pembrolizumab based on this clinical trial for gastric cancer tumors with MSI-H phenotype [35]. However, we must be cautious about an over-interpretation of the results because only 5 patients with gastric cancer were included in this trial and most of the patients assessed had colorectal cancer. Thus, further trials are needed to confirm the role of immunotherapy in MSI-H gastric cancer. As already mentioned above, the incidence of MSI-H phenotype in esophageal cancer is very low so the investigation of immunotherapy should be supported by a different rationale, e.g., squamous histology. Another potentially predictive factor is the PD-L1 expression. Keynote-012 was a phase Ib trial enrolling patients with PD-L1 positive gastric and gastroesophageal (GE) junction cancer who were treated with pembrolizumab $10 \mathrm{mg} / \mathrm{kg}$ biweekly until 24 months, progression, or unacceptable toxicity. In total, 39 patients were enrolled in this trial that showed promising $22 \%$ overall response rate and triggered the initiation of further trials [70]. The phase II trial Keynote-055 that followed had three cohorts of patients with recurrent or metastatic gastric or GE junction adenocarcinoma, including pretreated patients treated by pembrolizumab $200 \mathrm{mg}$ triweekly; patients treated in the first line with cisplatin and 5-FU or capecitabine in combination with pembrolizumab $200 \mathrm{mg}$ triweekly and patients treated in the first line with pembrolizumab $200 \mathrm{mg}$ triweekly alone. The trial showed overall response rate of $11.6 \%$ with median duration of the response 8.4 months. However, when patients were evaluated according to PD-L1 expression, overall response rate (ORR) was 15.5\% in PD-L1 expressing tumors and 6.4\% in PD-L1 negative tumors with median duration of response of 16.3 months in in patients with PD-L1 expressing tumors and only 6.9 months in patients with tumors not expressing PD-L1 [71]. Based on this first cohort of the Keynote-059 trial pembrolizumab gained FDA approval in previously treated PD-L1 positive gastric and GE junction cancer patients. However, optimism was cooled by the results of the Keynote-061 trial randomizing patients between pembrolizumab and an active comparator paclitaxel which did not show any significant benefit [72]. Also, it must be pointed out that paclitaxel as a comparator in the second line of the treatment is a suboptimal standard in this setting with the combination of paclitaxel and ramucirumab being currently the standard of care. Further trials such as Keynote-062 should further clarify the position of the pembrolizumab in the treatment of metastatic gastric cancer. Another checkpoint inhibitor, nivolumab, was investigated in the phase III Attraction-2 trial in heavily pretreated gastric and GE junction adenocarcinoma patients. The patients were randomized regarding treatment with nivolumab or with placebo. The administration of nivolumab extended median overall survival from 4.14 to 5.26 months. This benefit was significant in patients with PD-L1 positive and well as PD-L1 negative tumors [73]. Based on this trial, nivolumab has gained approval in Japan, but not by the FDA or EMA. At this moment, no immunotherapeutic agent is approved for the treatment of esophageal, gastric or GE junction cancer in Europe. Several trials are ongoing at this moment with immune checkpoint inhibitors, both anti-PD1 and anti-PD-L1 antibodies, investigating patients with gastric, GE junction or esophageal cancer not only in advanced/metastatic disease setting, but also in adjuvant, neoadjuvant, or perioperative indications.

\section{Conclusions}

At this moment, PD-L1 expression and MSI-H phenotype, although not ideal, seem to be major prognostic factors as well as predictive biomarkers for immunotherapy efficacy in gastric and esophageal cancer. Continuous research is needed to clarify further predictive factors which could 
identify the subgroup of patients who will benefit from immunotherapy the most, considering its significant cost, toxicity, and potential induction of the hyper-progression.

Funding: This research received no external funding.

Conflicts of Interest: The authors declare no conflict of interest.

\section{References}

1. Bray, F.; Ferlay, J.; Soerjomataram, I.; Siegel, R.L.; Torre, L.A.; Jemal, A. Global cancer statistics 2018: GLOBOCAN estimates of incidence and mortality worldwide for 36 cancers in 185 countries. CA Cancer J. Clin. 2018, 68, 394-424. [CrossRef] [PubMed]

2. Matzenauer, M.; Vrána, D.; Vlachová, Z.; Aujesky, R.; Vrba, R.; Neoral, C.; Melichar, B. Stereotactic radiotherapy in the treatment of local recurrences of esophageal cancer. Oncol. Lett. 2017, 13, 1807-1810. [CrossRef] [PubMed]

3. Vrana, D.; Matzenauer, M.; Aujesky, R.; Vrba, R.; Neoral, C.; Melichar, B.; Souček, P. Potential Predictive Role of MicroRNAs in the Neoadjuvant Treatment of Esophageal Cancer. Anticancer Res. 2017, 37, 403-412. [CrossRef]

4. Vrana, D.; Hlavac, V.; Brynychova, V.; Vaclavikova, R.; Neoral, C.; Vrba, J.; Aujesky, R.; Matzenauer, M.; Melichar, B.; Soucek, P. ABC Transporters and Their Role in the Neoadjuvant Treatment of Esophageal Cancer. Int. J. Mol. Sci. 2018, 19, 868. [CrossRef] [PubMed]

5. Hanahan, D.; Weinberg, R.A. Hallmarks of cancer: The next generation. Cell 2011, 144, 646-674. [CrossRef]

6. Marconcini, R.; Spagnolo, F.; Stucci, L.S.; Ribero, S.; Marra, E.; Rosa, F.; Picasso, V.; Di Guardo, L.; Cimminiello, C.; Cavalieri, S.; et al. Current status and perspectives in immunotherapy for metastatic melanoma. Oncotarget 2018, 9, 12452-12470. [CrossRef]

7. Santoni, M.; Massari, F.; Di Nunno, V.; Conti, A.; Cimadamore, A.; Scarpelli, M.; Montironi, R.; Cheng, L.; Battelli, N.; Lopez-Beltran, A. Immunotherapy in renal cell carcinoma: Latest evidence and clinical implications. Drugs Context 2018, 7, 212528. [CrossRef]

8. Cancer Genome Atlas Research Network. Integrated genomic characterization of oesophageal carcinoma. Nature 2017, 541, 169-175. [CrossRef]

9. Secrier, M.; Li, X.; de Silva, N.; Eldridge, M.D.; Contino, G.; Bornschein, J.; MacRae, S.; Grehan, N.; O'Donovan, M.; Miremadi, A.; et al. Oesophageal Cancer Clinical and Molecular Stratification (OCCAMS) Consortium. Mutational signatures in esophageal adenocarcinoma define etiologically distinct subgroups with therapeutic relevance. Nat. Genet. 2016, 48, 1131-1141. [CrossRef]

10. Cancer Genome Atlas Research Network. Comprehensive molecular characterization of gastric adenocarcinoma. Nature 2014, 513, 202-209. [CrossRef]

11. Alsaab, H.O.; Sau, S.; Alzhrani, R.; Tatiparti, K.; Bhise, K.; Kashaw, S.K.; Iyer, A.K. PD-1 and PD-L1 Checkpoint Signaling Inhibition for Cancer Immunotherapy: Mechanism, Combinations, and Clinical Outcome. Front. Pharmacol. 2017, 8, 561. [CrossRef] [PubMed]

12. Böger, C.; Behrens, H.M.; Mathiak, M.; Krüger, S.; Kalthoff, H.; Röcken, C. PD-L1 is an independent prognostic predictor in gastric cancer of Western patients. Oncotarget 2016, 7, 24269-24283. [CrossRef] [PubMed]

13. Pereira, M.A.; Ramos, M.F.K.P.; Faraj, S.F.; Dias, A.R.; Yagi, O.K.; Zilberstein, B.; Cecconello, I.; Alves, V.A.F.; de Mello, E.S.; Ribeiro, U., Jr. Clinicopathological and prognostic features of Epstein-Barr virus infection, microsatellite instability, and PD-L1 expression in gastric cancer. J. Surg. Oncol. 2018, 117, 829-839. [CrossRef] [PubMed]

14. Tamura, T.; Ohira, M.; Tanaka, H.; Muguruma, K.; Toyokawa, T.; Kubo, N.; Sakurai, K.; Amano, R.; Kimura, K.; Shibutani, M.; et al. Programmed Death-1 Ligand-1 (PDL1) Expression Is Associated with the Prognosis of Patients with Stage II/III Gastric Cancer. Anticancer Res. 2015, 35, 5369-5376. [PubMed]

15. Zhang, L.; Qiu, M.; Jin, Y.; Ji, J.; Li, B.; Wang, X.; Yan, S.; Xu, R.; Yang, D. Programmed cell death ligand 1 (PD-L1) expression on gastric cancer and its relationship with clinicopathologic factors. Int. J. Clin. Exp. Pathol. 2015, 8, 11084-11091. [PubMed]

16. Eto, S.; Yoshikawa, K. Programmed cell death protein 1 expression is an independent prognostic factor in gastric cancer after curative resection. Gastric Cancer 2016, 19, 466-471. [CrossRef] 
17. Tsutsumi, S.; Saeki, H.; Nakashima, Y.; Ito, S.; Oki, E.; Morita, M.; Oda, Y.; Okano, S.; Maehara, Y. Programmed death-ligand 1 expression at tumor invasive front is associated with epithelial-mesenchymal transition and poor prognosis in esophageal squamous cell carcinoma. Cancer Sci. 2017, 108, 1119-1127. [CrossRef]

18. Kim, R.; Keam, B.; Kwon, D.; Ock, C.Y.; Kim, M.; Kim, T.M.; Kim, H.J.; Jeon, Y.K.; Park, I.K.; Kang, C.H.; et al. Programmed death ligand-1 expression and its prognostic role in esophageal squamous cell carcinoma. World J. Gastroenterol. 2016, 22, 8389-8397. [CrossRef]

19. Zhang, W.; Pang, Q.; Zhang, X.; Yan, C.; Wang, Q.; Yang, J.; Yu, S.; Liu, X.; Pan, Y.; Yuan, Z.; et al. Programmed death-ligand 1 is prognostic factor in esophageal squamous cell carcinoma and is associated with epidermal growth factor receptor. Cancer Sci. 2017, 108, 590-597. [CrossRef]

20. Zhu, Y.; Li, M.; Mu, D.; Kong, L.; Zhang, J.; Zhao, F.; Li, Z.; Liu, X.; Bo, C.; Yu, J. CD8+ /FOXP3+ ratio and PD-L1 expression associated with survival in pT3N0M0 stage esophageal squamous cell cancer. Oncotarget 2016, 7, 71455-71465. [CrossRef]

21. Jiang, Y.; Lo, A.W.I.; Wong, A.; Chen, W.; Wang, Y.; Lin, L.; Xu, J. Prognostic significance of tumor-infiltrating immune cells and PD-L1 expression in esophageal squamous cell carcinoma. Oncotarget 2017, 8, 30175-30189. [CrossRef] [PubMed]

22. Jesinghaus, M.; Steiger, K.; Slotta-Huspenina, J.; Drecoll, E.; Pfarr, N.; Meyer, P.; Konukiewitz, B.; Bettstetter, M.; Wieczorek, K.; Ott, K.; et al. Increased intraepithelial CD3+ T-lymphocytes and high PD-L1 expression on tumor cells are associated with a favorable prognosis in esophageal squamous cell carcinoma and allow prognostic immunogenic subgrouping. Oncotarget 2017, 8, 46756-46768. [CrossRef] [PubMed]

23. Chen, M.F.; Chen, P.T.; Chen, W.C.; Lu, M.S.; Lin, P.Y.; Lee, KD. The role of PD-L1 in the radiation response and prognosis for esophageal squamous cell carcinoma related to IL-6 and T-cell immunosuppression. Oncotarget 2016, 7, 7913-7924. [CrossRef]

24. Kawazoe, A.; Kuwata, T.; Kuboki, Y.; Shitara, K.; Nagatsuma, A.K.; Aizawa, M.; Yoshino, T.; Doi, T.; Ohtsu, A.; Ochiai, A. Clinicopathological features of programmed death ligand 1 expression with tumor-infiltrating lymphocyte, mismatch repair, and Epstein-Barr virus status in a large cohort of gastric cancer patients. Gastric Cancer 2017, 20, 407-415. [CrossRef] [PubMed]

25. Thompson, E.D.; Zahurak, M.; Murphy, A.; Cornish, T.; Cuka, N.; Abdelfatah, E.; Yang, S.; Duncan, M.; Ahuja, N.; Taube, J.M.; et al. Patterns of PD-L1 expression and CD8 T cell infiltration in gastric adenocarcinomas and associated immune stroma. Gut 2017, 66, 794-801. [CrossRef]

26. Yang, J.H.; Kim, H.; Roh, S.Y.; Lee, M.A.; Park, J.M.; Lee, H.H.; Park, C.H.; Lee, H.H.; Jung, E.S.; Lee, S.H.; et al. Discordancy and changes in the pattern of programmed death ligand 1 expression before and after platinum-based chemotherapy in metastatic gastric cancer. Gastric Cancer 2018, 1-8. [CrossRef] [PubMed]

27. Seo, A.N.; Kang, B.W.; Kwon, O.K.; Park, K.B.; Lee, S.S.; Chung, H.Y.; Yu, W.; Bae, H.I.; Jeon, S.W.; Kang, H.; et al. Intratumoural PD-L1 expression is associated with worse survival of patients with Epstein-Barr virus-associated gastric cancer. Br. J. Cancer 2017, 117, 1753-1760. [CrossRef]

28. Ito, S.; Okano, S.; Morita, M.; Saeki, H.; Tsutsumi, S.; Tsukihara, H.; Nakashima, Y.; Ando, K.; Imamura, Y.; Ohgaki, K.; et al. Expression of PD-L1 and HLA Class I in Esophageal Squamous Cell Carcinoma: Prognostic Factors for Patient Outcome. Ann. Surg. Oncol. 2016, 23 (Suppl. S4), 508-515. [CrossRef]

29. Hsieh, C.C.; Hsu, H.S.; Li, A.F.; Chen, Y.J. Clinical relevance of PD-L1 and PD-L2 overexpression in patients with esophageal squamous cell carcinoma. J. Thorac. Dis. 2018, 10, 4433-4444. [CrossRef]

30. Kollmann, D.; Ignatova, D.; Jedamzik, J.; Chang, Y.T.; Jomrich, G.; Baierl, A.; Kazakov, D.; Michal, M.; French, L.E.; Hoetzenecker, W.; et al. PD-L1 expression is an independent predictor of favorable outcome in patients with localized esophageal adenocarcinoma. Oncoimmunology 2018, 7, e1435226. [CrossRef]

31. Tanaka, K.; Miyata, H.; Sugimura, K.; Kanemura, T.; Hamada-Uematsu, M.; Mizote, Y.; Yamasaki, M.; Wada, H.; Nakajima, K.; Takiguchi, S.; et al. Negative influence of programmed death-1-ligands on the survival of esophageal cancer patients treated with chemotherapy. Cancer Sci. 2016, 107, 726-733. [CrossRef] [PubMed]

32. Li, Z.; Lai, Y.; Sun, L.; Zhang, X.; Liu, R.; Feng, G.; Zhou, L.; Jia, L.; Huang, X.; Kang, Q.; et al. PD-L1 expression is associated with massive lymphocyte infiltration and histology in gastric cancer. Hum. Pathol. 2016, 55, 182-189. [CrossRef] [PubMed]

33. Wang, L.; Zhang, Q.; Ni, S.; Tan, C.; Cai, X.; Huang, D.; Sheng, W. Programmed death-ligand 1 expression in gastric cancer: Correlation with mismatch repair deficiency and HER2-negative status. Cancer Med. 2018, 7, 2612-2620. [CrossRef] [PubMed] 
34. Saito, R.; Abe, H.; Kunita, A.; Yamashita, H.; Seto, Y.; Fukayama, M. Overexpression and gene amplification of PD-L1 in cancer cells and PD-L1 ${ }^{+}$immune cells in Epstein-Barr virus-associated gastric cancer: The prognostic implications. Mod. Pathol. 2017, 30, 427-439. [CrossRef] [PubMed]

35. Cho, J.; Lee, J.; Bang, H.; Kim, S.T.; Park, S.H.; An, J.Y.; Choi, M.G.; Lee, J.H.; Sohn, T.S.; Bae, J.M.; et al. cell death-ligand 1 expression predicts survival in patients with gastric carcinoma with microsatellite instability. Oncotarget 2017, 8, 13320-13328. [CrossRef]

36. Ma, C.; Patel, K.; Singhi, A.D.; Ren, B.; Zhu, B.; Shaikh, F.; Sun, W. Programmed Death-Ligand 1 Expression Is Common in Gastric Cancer Associated with Epstein-Barr Virus or Microsatellite Instability. Am. J. Surg. Pathol. 2016, 40, 1496-1506. [CrossRef]

37. Koh, J.; Ock, C.Y.; Kim, J.W.; Nam, S.K.; Kwak, Y.; Yun, S.; Ahn, S.H.; Park, D.J.; Kim, H.H.; Kim, W.H.; et al. Clinicopathologic implications of immune classification by PD-L1 expression and CD8-positive tumor-infiltrating lymphocytes in stage II and III gastric cancer patients. Oncotarget 2017, 8, 26356-26367. [CrossRef]

38. An Investigational Immuno-therapy Study of Nivolumab or Placebo in Patients With Resected Esophageal or Gastroesophageal Junction Cancer (CheckMate 577). Available online: https: / clinicaltrials.gov/ct2/ show / NCT02743494 (accessed on 13 November 2018).

39. Antonia, S.J.; Villegas, A.; Daniel, D.; Vicente, D.; Murakami, S.; Hui, R.; Kurata, T.; Chiappori, A.; Lee, K.H.; de Wit, M.; et al. PACIFIC Investigators. Overall Survival with Durvalumab after Chemoradiotherapy in Stage III NSCLC. N. Engl. J. Med. 2018, 379, 2342-2350. [CrossRef]

40. Tang, Y.; Li, G.; Wu, S.; Tang, L.; Zhang, N.; Liu, J.; Zhang, S.; Yao, L. Programmed death ligand 1 expression in esophageal cancer following definitive chemoradiotherapy: Prognostic significance and association with inflammatory biomarkers. Oncol. Lett. 2018, 15, 4988-4996. [CrossRef]

41. Minsky, B.D.; Pajak, T.F.; Ginsberg, R.J.; Pisansky, T.M.; Martenson, J.; Komaki, R.; Okawara, G.; Rosenthal, S.A.; Kelsen, D.P. INT 0123 (Radiation Therapy Oncology Group 94-05) phase III trial of combined-modality therapy for esophageal cancer: High-dose versus standard-dose radiation therapy. J. Clin. Oncol. 2002, 20, 1167-1174. [CrossRef]

42. Dovedi, S.J.; Adlard, A.L.; Lipowska-Bhalla, G.; McKenna, C.; Jones, S.; Cheadle, E.J.; Stratford, I.J.; Poon, E.; Morrow, M.; Stewart, R.; et al. Acquired resistance to fractionated radiotherapy can be overcome by concurrent PD-L1 blockade. Cancer Res. 2014, 74, 5458-5468. [CrossRef] [PubMed]

43. Mimura, K.; Teh, J.L.; Okayama, H.; Shiraishi, K.; Kua, L.F.; Koh, V.; Smoot, D.T.; Ashktorab, H.; Oike, T.; Suzuki, Y.; et al. PD-L1 expression is mainly regulated by interferon gamma associated with JAK-STAT pathway in gastric cancer. Cancer Sci. 2018, 109, 43-53. [CrossRef] [PubMed]

44. Ghebeh, H.; Lehe, C.; Barhoush, E.; Al-Romaih, K.; Tulbah, A.; Al-Alwan, M.; Hendrayani, S.F.; Manogaran, P.; Alaiya, A.; Al-Tweigeri, T.; et al. Doxorubicin downregulates cell surface B7-H1 expression and upregulates its nuclear expression in breast cancer cells: Role of B7-H1 as an anti-apoptotic molecule. Breast Cancer Res. 2010, 12, R48. [CrossRef] [PubMed]

45. Rom-Jurek, E.M.; Kirchhammer, N.; Ugocsai, P.; Ortmann, O.; Wege, A.K.; Brockhoff, G. Regulation of Programmed Death Ligand 1 (PD-L1) Expression in Breast Cancer Cell Lines In Vitro and in Immunodeficient and Humanized Tumor Mice. Int. J. Mol. Sci. 2018, 19, 563. [CrossRef]

46. Min, Z.; Yibo, F.; Xiaofang, C.; Kezuo, H.; Xiujuan, Q. 5-Fluorouracil induced up-regulation of exosomal PD-L1 causing immunosuppression in gastric cancer patients. Ann. Oncol. 2018, 29. [CrossRef]

47. Fang, W.; Zhang, J.; Hong, S.; Zhan, J.; Chen, N.; Qin, T.; Tang, Y.; Zhang, Y.; Kang, S.; Zhou, T.; et al. EBV-driven LMP1 and IFN- $\gamma$ up-regulate PD-L1 in nasopharyngeal carcinoma: Implications for oncotargeted therapy. Oncotarget 2014, 5, 12189-12202. [CrossRef]

48. Kim, J.H.; Park, H.E.; Cho, N.Y.; Lee, H.S.; Kang, G.H. Characterisation of PD-L1-positive subsets of microsatellite-unstable colorectal cancers. Br. J. Cancer 2016, 115, 490-496. [CrossRef] [PubMed]

49. Chen, L.; Xiong, Y.; Li, J.; Zheng, X.; Zhou, Q.; Turner, A.; Wu, C.; Lu, B.; Jiang, J. PD-L1 Expression Promotes Epithelial to Mesenchymal Transition in Human Esophageal Cancer. Cell Physiol. Biochem. 2017, 42, 2267-2280. [CrossRef]

50. Ng, H.Y.; Li, J.; Tao, L.; Lam, A.K.; Chan, K.W.; Ko, J.M.Y.; Yu, V.Z.; Wong, M.; Li, B.; Lung, M.L. Chemotherapeutic Treatments Increase PD-L1 Expression in Esophageal Squamous Cell Carcinoma through EGFR/ERK Activation. Transl. Oncol. 2018, 11, 1323-1333. [CrossRef] 
51. Chen, K.; Cheng, G.; Zhang, F.; Zhang, N.; Li, D.; Jin, J.; Wu, J.; Ying, L.; Mao, W.; Su, D. Prognostic significance of programmed death-1 and programmed death-ligand 1 expression in patients with esophageal squamous cell carcinoma. Oncotarget 2016, 7, 30772-30780. [CrossRef]

52. Wu, Y.; Cao, D.; Qu, L.; Cao, X.; Jia, Z.; Zhao, T.; Wang, Q.; Jiang, J. PD-1 and PD-L1 co-expression predicts favorable prognosis in gastric cancer. Oncotarget 2017, 8, 64066-64082. [CrossRef] [PubMed]

53. Vanderwalde, A.; Spetzler, D.; Xiao, N.; Gatalica, Z.; Marshall, J. Microsatellite instability status determined by next-generation sequencing and compared with PD-L1 and tumor mutational burden in 11,348 patients. Cancer Med. 2018, 7, 746-756. [CrossRef] [PubMed]

54. Kim, K.J.; Lee, K.S.; Cho, H.J.; Kim, Y.H.; Yang, H.K.; Kim, W.H.; Kang, G.H. Prognostic implications of tumor-infiltrating FoxP3+ regulatory T cells and CD8+ cytotoxic T cells in microsatellite-unstable gastric cancers. Hum. Pathol. 2014, 45, 285-293. [CrossRef]

55. Boissière-Michot, F.; Lazennec, G.; Frugier, H.; Jarlier, M.; Roca, L.; Duffour, J.; Du Paty, E.; Laune, D.; Blanchard, F.; Le Pessot, F.; et al. Characterization of an adaptive immune response in microsatellite-instable colorectal cancer. Oncoimmunology 2014, 3, e29256. [CrossRef]

56. Polom, K.; Böger, C.; Smyth, E.; Marrelli, D.; Behrens, H.M.; Marano, L.; Becker, T.; Lordick, F.; Röcken, C.; Roviello, F. Synchronous metastatic gastric cancer-molecular background and clinical implications with special attention to mismatch repair deficiency. Eur. J. Surg. Oncol. 2018, 44, 626-631. [CrossRef] [PubMed]

57. Corso, G.; Pedrazzani, C.; Marrelli, D.; Pascale, V.; Pinto, E.; Roviello, F. Correlation of microsatellite instability at multiple loci with long-term survival in advanced gastric carcinoma. Arch. Surg. 2009, 144, 722-727. [CrossRef]

58. Muzeau, F.; Fléjou, J.F.; Belghiti, J.; Thomas, G.; Hamelin, R. Infrequent microsatellite instability in oesophageal cancers. Br. J. Cancer 1997, 75, 1336-1339. [CrossRef]

59. Smyth, E.C.; Wotherspoon, A.; Peckitt, C.; Gonzalez, D.; Hulkki-Wilson, S.; Eltahir, Z.; Fassan, M.; Rugge, M.; Valeri, N.; Okines, A.; et al. Mismatch Repair Deficiency, Microsatellite Instability, and Survival: An Exploratory Analysis of the Medical Research Council Adjuvant Gastric Infusional Chemotherapy (MAGIC) Trial. JAMA Oncol. 2017, 3, 1197-1203. [CrossRef]

60. Pembrolizumab in MSI-H or dMMR Solid Tumors: 'First Tissue/Site-Agnostic' Approval by FDA. Available online: http: / / www.ascopost.com/issues / february-10-2018/pembrolizumab-in-msi-h-or-dmmr-solidtumors-first-tissuesite-agnostic-approval-by-fda/ (accessed on 13 November 2018).

61. Kim, H.; An, J.Y.; Noh, S.H.; Shin, S.K.; Lee, Y.C.; Kim, H. High microsatellite instability predicts good prognosis in intestinal-type gastric cancers. J. Gastroenterol. Hepatol. 2011, 26, 585-592. [CrossRef]

62. An, J.Y.; Kim, H.; Cheong, J.H.; Hyung, W.J.; Kim, H.; Noh, S.H. Microsatellite instability in sporadic gastric cancer: Its prognostic role and guidance for 5-FU based chemotherapy after R0 resection. Int. J. Cancer 2012, 131, 505-511. [CrossRef]

63. Fang, W.L.; Chang, S.C.; Lan, Y.T.; Huang, K.H.; Chen, J.H.; Lo, S.S.; Hsieh, M.C.; Li, A.F.; Wu, C.W.; Chiou, S.H. Microsatellite instability is associated with a better prognosis for gastric cancer patients after curative surgery. World J. Surg. 2012, 36, 2131-2138. [CrossRef] [PubMed]

64. Beghelli, S.; de Manzoni, G.; Barbi, S.; Tomezzoli, A.; Roviello, F.; Di Gregorio, C.; Vindigni, C.; Bortesi, L.; Parisi, A.; Saragoni, L.; et al. Microsatellite instability in gastric cancer is associated with better prognosis in only stage II cancers. Surgery 2006, 139, 347-356. [CrossRef] [PubMed]

65. Kim, S.Y.; Choi, Y.Y.; An, J.Y.; Shin, H.B.; Jo, A.; Choi, H.; Seo, S.H.; Bang, H.J.; Cheong, J.H.; Hyung, W.J.; et al. The benefit of microsatellite instability is attenuated by chemotherapy in stage II and stage III gastric cancer: Results from a large cohort with subgroup analyses. Int. J. Cancer 2015, 137, 819-825. [CrossRef] [PubMed]

66. Giampieri, R.; Maccaroni, E.; Mandolesi, A.; Del Prete, M.; Andrikou, K.; Faloppi, L.; Bittoni, A.; Bianconi, M.; Scarpelli, M.; Bracci, R.; et al. Mismatch repair deficiency may affect clinical outcome through immune response activation in metastatic gastric cancer patients receiving first-line chemotherapy. Gastric Cancer 2017, 20, 156-163. [CrossRef]

67. Oki, E.; Kakeji, Y.; Zhao, Y.; Yoshida, R.; Ando, K.; Masuda, T.; Ohgaki, K.; Morita, M.; Maehara, Y. Chemosensitivity and survival in gastric cancer patients with microsatellite instability. Ann. Surg. Oncol. 2009, 16, 2510-2515. [CrossRef] [PubMed] 
68. Falchetti, M.; Saieva, C.; Lupi, R.; Masala, G.; Rizzolo, P.; Zanna, I.; Ceccarelli, K.; Sera, F.; Mariani-Costantini, R.; Nesi, G.; et al. Gastric cancer with high-level microsatellite instability: Target gene mutations, clinicopathologic features, and long-term survival. Hum Pathol. 2008, 39, 925-932. [CrossRef] [PubMed]

69. Marrelli, D.; Polom, K.; Pascale, V.; Vindigni, C.; Piagnerelli, R.; De Franco, L.; Ferrara, F.; Roviello, G.; Garosi, L.; Petrioli, R.; et al. Strong Prognostic Value of Microsatellite Instability in Intestinal Type Non-cardia Gastric Cancer. Ann. Surg. Oncol. 2016, 23, 943-950. [CrossRef] [PubMed]

70. Muro, K.; Chung, H.C.; Shankaran, V.; Geva, R.; Catenacci, D.; Gupta, S.; Eder, J.P.; Golan, T.; Le, D.T.; Burtness, B.; et al. Pembrolizumab for patients with PD-L1-positive advanced gastric cancer (KEYNOTE-012): A multicentre, open-label, phase $1 \mathrm{~b}$ trial. Lancet Oncol. 2016, 17, 717-726. [CrossRef]

71. Fuchs, C.S.; Doi, T.; Jang, R.W.; Muro, K.; Satoh, T.; Machado, M.; Sun, W.; Jalal, S.I.; Shah, M.A.; Metges, J.P.; et al. Safety and Efficacy of Pembrolizumab Monotherapy in Patients with Previously Treated Advanced Gastric and Gastroesophageal Junction Cancer: Phase 2 Clinical KEYNOTE-059 Trial. JAMA Oncol. 2018, 4, e180013. [CrossRef]

72. Shitara, K.; Özgüroğlu, M.; Bang, Y.J.; Di Bartolomeo, M.; Mandalà, M.; Ryu, M.H.; Fornaro, L.; Olesiński, T.; Caglevic, C.; Chung, H.C.; et al. Pembrolizumab versus paclitaxel for previously treated, advanced gastric or gastro-oesophageal junction cancer (KEYNOTE-061): A randomised, open-label, controlled, phase 3 trial. Lancet 2018, 392, 123-133. [CrossRef]

73. Kang, Y.K.; Boku, N.; Satoh, T.; Ryu, M.H.; Chao, Y.; Kato, K.; Chung, H.C.; Chen, J.S.; Muro, K.; Kang, W.K.; et al. Nivolumab in patients with advanced gastric or gastro-oesophageal junction cancer refractory to, or intolerant of, at least two previous chemotherapy regimens (ONO-4538-12, ATTRACTION-2): A randomised, double-blind, placebo-controlled, phase 3 trial. Lancet 2017, 390, 2461-2471. [CrossRef]

(C) 2018 by the authors. Licensee MDPI, Basel, Switzerland. This article is an open access article distributed under the terms and conditions of the Creative Commons Attribution (CC BY) license (http:/ / creativecommons.org/licenses/by/4.0/). 